\title{
International law, human rights and the transformative occupation of Iraq
}

\author{
PETER G. DANCHIN
}

\section{Introduction}

This chapter examines the project of transformative occupation undertaken by the United States and its allies following the invasion of Iraq in 2003. More specifically, it considers the US occupation in light of two competing sensibilities in international legal argument. On one view, which I term 'legal formalism', the purpose of international law is eclectic, intersubjective and value-pluralist: to create the conditions for peaceful coexistence between different political orders and ways of life. This view is commonly associated with the liberalism of the United Nations (UN) Charter, ${ }^{1}$ which posits both the subject of international law and its liberty in formal terms as 'the state' and 'sovereign equality' respectively. On a rival view, which I term 'instrumental anti-pluralism', the purpose of international law is to project a universal regime based on a rationally reconstructed and universally authoritative morality. Here the identity of the sovereign as a subject of international law is understood in material terms as 'the liberal democratic state' and sovereignty is understood as the equal treatment of legal subjects so defined. ${ }^{2}$

The defining feature of the anti-pluralist view is the notion that the internal characteristics of a state determine its standing in the family of nations. Undemocratic, illiberal, or so-called 'rogue' states such as Iraq are not to be regarded as full members of international society and are

${ }^{1}$ Charter of the United Nations, opened for signatute 26 June 1945, preatnble, Arts, 1, 55 (entered into force 24 October 1945) ('UN Charter').

2 For general discussion of these two views, see Gerry Simpson, "Two liberalisms" (2001) 12 European Journal of International Law, 537-72; John Gray, Two Faces of Liberalism (Cambridge: Polity Press, 2000); William A. Galston, 'Two concepts of liberalism' (1995) 105 Fthics, 516-34. 
seen to lie outside of the zone of law. ${ }^{3}$ Like colonialism by European nation states during the nineteenth century, the project of military occupation is intended to transform or civilise the internal identity of such states in order to bring them into the community of democratic nations. This is precisely the type of action that legal formalism, with its underlying rationale of liberal toleration and political inclusion, had hoped to prevent. As a normative matter, the justification for transformative occupation is a purportedly universal body of international human-rights norms finding its origin in Enlightenment notions of individual autonomy and popular sovereignty. ${ }^{4}$ While such norms lie beyond consent, their legitimacy in practice depends on their formalism - their acceptability to, and apparent compatibility with, divergent cultural, religious and ideological ways of life.

In this chapter, I argue that the attempt to transform the Iraqi constitutional structure via military occupation illustrates the complex dialectic between the formal and instrumental views, a dialectic that oscillates precariously between imperial imposition in the name of liberal democracy on the one hand, and a desperate attempt to secure internal legitimation for the new political order on the other. ${ }^{5}$ The role of international law in this process is ambiguous and paradoxical. On one hand, the law assumes an instrumentalist anti-formal guise facilitating the external project of imposing subjective material norms on a resistant political order. On the other hand, it provides a formal anti-instrumental site of deliberation, contestation and struggle critical to the internal project of the emergence of a distinctly Iraqi constitutionalism. The contradictions generated by this dialectic allow us to see how international law both constructs and mediates between certain 'internal' and 'external' forms of rationality.

One consequence of this dialectic structure is that both sets of actors invoke both views in their struggle and interaction with each other. They do so from opposing starting points, before tacitly switching to the view

${ }^{3}$ Farold Hongju Koh, 'Why do nations obey international law?' (1997) 106 Yale Law Journal, 2599-59, 2633; Anne-Marie Slaughter', 'International law in a world of liberal states' (1995) 6 European Journal of International Law, 503-38.

"See, e.g. Fernando R. Tesón. "The Kantian theory of international law' (1992) 92 Columbia Law Review, 53-102, 54.

5 For discussion of how the transformative model of military occupation in Iraq has created a 'precarions dialectic between subordination and legitimation', see Nehal Bhuta, 'The ancinomies of transiormative occupation' (2005) 16 Luropeat Journal of International Law, $721-40,724$. 
adopted initially by their opponent. Thus, the initial positions adwocated by the US as its blueprint for constitutional transformation in Iraq were premised on notions of 'liberal' democracy, 'individual' rights, and 'free' markets - strongly instrumentalist values lying beyond the prescriptive nomativity of contemporary international law. In response, Iraq invoked formal norms of sovereignty, self-determination and non-intervention strongly anti-instrumental norms of international law. Facing intensifying resistance to its project of forced transformation, the US then sought to engage with Iraqi culture and values by positing formal conceptions of its objectives. Assertions of liberal rights became claims to human rights; assertions of liberal democracy became simply claims to democracy. Conversely, Iraqi political factions now assumed more instrumental and anti-pluralist positions as they asserted distinctive claims to Islamic democracy, Islamic human rights, and ultimately to Islamic international law.

The argument proceeds in three parts. Part I sets out the general features of the rival formal and anti-formal guises of international legal argument. Part II considers how these two sensibilities have shaped the role and application of occupation law, occupatio bellica, in Iraq. Part III discusses how the relationship between religion and state has been contested and understood in the post- 2003 constitutional-reform process. The chapter concludes with observations on the potential of international law to secure justice and democracy in societies subjected to 'occupation as liberation'.

\section{I. 'The gift of formalism in international law}

The modern structure of international law is liberal, eclectic and intersubjective. The subject of the law is the 'state' and the state's liberty is based on the foundational norm of sovereign equality. The animating virtues of the modern view are notions of peace, toleration and valuepluralism. These notions are suspended precariously, however, between two other virtues that international law simultaneously seeks to incorporate and mediate: the seemingly opposing ideas of justice and consent. On their own, these two virtues appear to threaten the coherence of international law qua law: justice because it substitutes vague and subjective ideas about international morality for the rules actually obtaining between states: ${ }^{6}$ consent because it identifies international law primarily

${ }^{6}$ Jolın Austin, Province of Jurisprudence Detemined (Wilfred E. Rumble (ed,)) (Cambridge: Cambridge Untwersity Press, 1995). 
with state will, thus making it external municipal law." International law tries valiantly to maintain its autonomy qua law by seeking to reconcile these seeming opposites within a single form. It does so in two ways: first, by positing a social ethics (formal positivism) expressing the freedom of each state as a function of commumity values and justice; second, by positing an individual morality (humanistic universalism) which expresses the international community as a function of each states unique identity and awareness. ${ }^{7}$ This dialectic structure creates the distinctive double bind of international legal argument.

T'Tere are powerful historical reasons for the inherent tension within each strand of argument. Let us consider, for example, the latter idea of humanistic universalism. Early modern thought in international law was premised on a natural morality that asserted a universal law derived from reason that was applicable to all peoples. When in the late sixteenth century Francisco de Vitoria wrote about the rights of the Spanish and the Indians of the Americas, he regarded Indian and Spanish sovereignty as 'coterminous with each other' and the question to be determined 'how God had given possession to the Indians and what conditions the Spanish must fulfill in order to gain possession rightfully'.1.1 Missing from the logic of Vitoria's argument was the modern dialectic of the double bind. There was no initial assumption of either the Prince's or Indians' sphere of liberty or 'sovereignty' having an independent normative status in the form of 'statehood'. Rather, sovereignty described the 'powers and liberties which the Prince was endowed with by the normative code." "Thus, while international law was universal and the Spanish and the Indians its subjects alike, the pre-classical jurisprudence of the scholastics was

${ }^{7}$ Georg fellinek, Die Rechtiche Natur der Staatanverträge (Vienna: Hölder, 1890).

* Charter of the United Nations, opened for signature 26 Yune 1945, Art. 2(1) (entered into force 24 October 1945) ("UN Charter") provides that the United Nations "is based on the principle of the sovereign equality of all its [Member States]'. The Clarter begins from at presumption of initial state freedom. But as soon as states are regarded as members of an intemational comnunity, this initial state freecom is limited by the normative demands of the same 'equal' freedom of other states.

9 Article 2(7) of the UN Charter provides that Nothing contained in the present Charter shall authorize the United Nations to intervene in matters which are essentially within the domestic jurisdiction of any state. While international law is normatiwely universal and binding on all states, it is limited by the factual existence and unique 'internal' identity of and thus need for consent of each state.

${ }^{10}$ Francisco de Vitoria, De indis et de iare belli relectiones (Ernest Nys (ed.)) (Washington DC: Carnegie Institution of Washington, 1917), sect. I, 116, 120-8.

11 Marti Koskenniemi, From Apology to Vtopia: 'The structure of internntional legal argument (Helsinki; Lakimiesliton Kustannus, 1989), 192. 
expressed not as a function of each subject's unique identity and awareness, but as a function solely of community values and justice. Being an exercise in deductive reasoning from a single comprehensive value system, this was necessarily subjective in two senses: first, it was utopian in the form of European prejudice (the particular masquerading as the universal) and second, it was apologist in justifying imperial domination of other cultures.

By contrast, consider the idea of formal positivism. Nineteenth-century international legal thought was premised on the notion that states, as the principal subjects of the law, were bound only by those rules to which they had consented. The long history of European imperialism was marked, however, by the refusal of European nation-states to recognise non-European states as having 'sovereignty' and thus possessing formal legal personality under international law. On this view, international law distinguished between civilised and non-civilised states and applied only as between the civilised "Family of Nations. ${ }^{12}$ The duty of civilised nations was thus to civilise non-European states - by consent (acquiescence) or, if necessary, by force - in order to assimilate them into the nomos of European international law. Missing from this argument was the modern notion of formal subjecthood - of the 'state' as opposed to the 'civilised state' as the proper subject of international law.

For nineteenth-century positivism the 'State - and a set of rights associated with it - is the professional a priori, the transcendental condition from which discourse proceeds and which itself is not subject to discussion'. ${ }^{3}$ We see this in the writing of nineteenth-century international lawyers, such as James Lorimer and Robert Phillimore, who both equated Christianity with the highest form of civilisation and who, as Noyes observes;

placed nations whose views they associated with Christianity in a superior position concerning their international legal rights and obligations vis-a-vis certatn other nations. Their view of the superiority of this religious system helped them to justify a world in which it was difficult for non-luropean States, entities and peoples to be entitled to participate fully in an international legal community. ${ }^{\text {at }}$

${ }^{12}$ Antony Anghie, 'Finding the peripheries: Sovereignty and colonialism in nineteenthcentury international law' (1999) $40 \mathrm{Hamard} \mathrm{International} \mathrm{Law} \mathrm{Journal,} \mathrm{1-80,} 4$.

${ }_{13}$ Koskennieni, From Apology to Utopia, 107.

14 John E. Noyes, "Christianity and late nineteenth+century Brilish theories of international law' in Mark W. Janis (ed.), The Influence of Reigion on the Development of International Law (Dordrecht: Martinus Nijhoff Publishers, 1991), 85-106, 86. 
Both the naturalist universalism of the sixteenth and seventeenth centuries and the imperial positivism of the nineteenth century expressed one-sided unities. 'They reveal how the non-European periphery could become included in the European core in not one but two distinct ways: either by the erasure of the identity of the other in the name of a single societas humanae, or by forceful embrace such that the identity and subjectivity of the other would slowly take the form of the European state, that is as the single representative form of humanity. ${ }^{15}$ In the case of the former, community was defined according to a one-sided, subjective account of autonomy; in the case of the latter, autonomy was defined according to a one-sided, subjective account of community; and in both cases, the process of transformation was unidirectional: the nonEuropean was required to change in accordance with European projections of both the subject and its liberty.

Modern international law seeks to overcome these two pathologies by describing social life among states in terms of both community and autonomy and by defining each of these ideals in terms of the other. This, in turn, generates inherently conflicting demands for freedom and order. Thus:

\begin{abstract}
In the one case, community is interpreted as negative collectivism and autonomy (independence, self-determination) is presented as the normative goal. In the other, autonomy is interpreted as negative egoism and community (integration, solidarity) as what the law should aim at. Neither community nor autonony can be exclusive goals. To think of community as the ultimate goal seems utopian: as there is no agreement on the character of a desirable community, attempts to impose it seem like imperalism in disguise. To think of autonomy as the normative aim seems apologist: it strengthens the absolutist claims of national powerelites and supports their pursuits at intemational doninance.
\end{abstract}

In this way, each strand of argument generates its opposite within itself. The humanistic universalism of the communitarian argument is limited by implicit acknowledgement of the boundaries and finitude of deontological reasoning (whether arrived at from notions of God or Natural Reason) and thus by the unavoidability of pluralism and reasonable disagreement. The moral notion of universal right is thus premised on the idea of a social ethics; that is, the claim that all moral norms must

${ }^{1.5}$ Martti Koskenniemi, 'The civilizing mission: International law and the colonial encountet in the late 19th centuly' (Paper presented at Rechtshistorikertag, Bonn, 12-17 September 2004), 6-8.

${ }^{16}$ Koskenniemi, From Apology to Utopia, 424. 
be intersubjectively contested and justified. In this way, communityoriented arguments contain within themselves the normative aims of self-determination and may be constructed without lapsing into totalitarianism. Conversely, the formal positivism (or legal formalism) of the autonomy argument is premised on a moral idea: the duty to respect the autonomy of others as 'reason-giving' and 'reason-receiving' subjects. This idea underlies the universal norm of inclusion and formal status as a legal subject in the first place. In this way, autonomy-oriented arguments contain within them the normative aims of communal integration and solidarity and may be constructed without degenerating in to unlimited egoism.

The international legal project is driven by this dialectic which creates a dynamics of contradiction and constant oscillation between patterns of argument seeking to legitimate social order against individual freedom. In order to imagine the project as coherent, one first needs to assume some kind of notion of a 'harmony of interests': the presence or attainability of 'an underlying convergence between apparently conflicting State interests: ${ }^{\prime \prime}$ In a pluralistic world of different peoples, religions, cultures, languages, ideologies and ways of life, however, this assumption is questionable. What if, for example, the fundamental interests and ends of states are inherently incompatible? How is a political community defined by the rule of law premised on some notion of shared interests and values beyond the state to be imagined or realised in such circumstances?

\section{A. Formalism and instrumentalism}

The traditional response to this dilemma has been to employ the technique of legal formalism. International law is seen to provide the "flat substanceless surface" [which] expresses the universalist principle of inclusion at the outset and makes possible the regulative ideal of a pluralistic international world'. This is absolutely critical as the form of the law:

constructs political adversaries as equals, entitled to express their subjectively felt injustices in terms of breaches of the rules of the community to which they belong no less than their adversaries +. thus affirming both that inclusion and the principle that the conditions applying to

17 Marti Koskennicni, 'What is international law for?' in Malcolm D. Irans (ed.), International Law (Oxford: Oxford University Press, 2003), 89-114, 92. 
the treatment of any one member of the community must apply to every other member as well. ${ }^{18}$

In any decision to attach meaning to legal norms, sovereign equality means that states can articulate their interpretations on conditions of equal standing. They are thus included in the normative universe as subjects of rights and duties or carriers of distinct identities'. It is only because the regime comprises non-instrumental rules (that is, "understood to be authoritative independent of particular beliefs or purposes') that the freedom of its subjects to be different becomes possible. ${ }^{19}$ 'This has been described as the 'gift of formalism'. ".

On this view, international law is best understood as a project to reconcile the conflicting claims to freedom of differently situated subjects and the divergent assertions of right and justice to which they continually give rise. International law, in other words, is ineliminably intersubjective. If political power is to be employed in the name of some common social end - say, to protect international peace, or security or justice such that the sovereignty of a particular state is to be limited, then that power must be exercised according to legal norms and thereby justified to the state so affected. This remains the case even though states may differ greatly in their comprehensive views about the good and true way of life.

This is an attractive picture so far as it goes. The problem is that any argument for such a formal view is ambiguous. For one thing, no formal doctrine of sources of law will be able to exclude political considerations." For another, any notion of a 'pure' or 'complete' theory of law is vulnerable to familiar charges levelled against doctrinal utopianism and its disconnectedness from actual state interests, values and ends. ${ }^{2}$ What if, for example, a state asserts that its sovereignty derives not from some imagined, pre-social liberty but ultimately from God? Or, conversely, a state asserts that its sovereignty is subject to no external limit other than that to which it expressly consents?

18 Thid., 102-3.

19 See Terry Nardin, 'Legal positivism as a theory of international society' in David R. Mapel and Terry Nardin (eds.), Intemational Society: Diverse efhical perspectives (Princeton: Princeton University Press, 1998), 17-35, 31, ciled in Koskenniemi, "What is international law for?', 102.

20 Anne Orford, "The gift of formalism" (2004) 15 European Journal of Intemational Law, 179-95.

21 Koskenniemi, From Apology to Utopia, 29. ${ }^{22}$ ibth. 28. 
'These questions compel us to look behind the 'formal validity' or 'binding force' of legal norms and to consider the purpose of or reasons justifying such norms. ${ }^{21}$ 'This generates an 'anti-formal' mode of reasoning which defines itself in response to the criticisms of formalism. On this view, the traditional attributes of sovereignty - political independence, autonomy, dignity, territorial integrity - are merely legal forms. What really counts is whether they help or hinder certain (as-yet unspecified) objectives, values or ends. Do these formal rules, for example, stand in the way of protecting fundamental norms of democracy and human rights? Do they shield undemocratic states which lack a system of government based on free periodic elections and are unaccountable to their citizens? Do they shield illiberal states which fail to offer their citizens individual rights?

These examples teveal, however, the dangers of instrumentalist reasoning. If international law is judged in terms of its instrumental effectiveness, it soon becomes an apology for the (contested) interests or ends of powerful states. Moreover, by emphasising concreteness the law risks losing its binding force and normativity altogether. International law may in this way legitimise force as 'enforcement' in a manner that conflicts directly with the target state's self-understanding. To offset these dangers, instrumentalist reasoning tacitly resorts to naturalistic or 'objective' ideas of justice. 'The fundamental norms of democracy and human rights are not just American or Western but universal values arrived at by rational consensus and expressing ideals which either are, or should be, embedded in international law as an expression of 'international right'. A useful articulation of this deep-seated vein of thought in American historical consciousness is Paine's classic statement that "The cause of America is in a great measure the cause of all mankind.". ${ }^{2}$

In this way, anti-formalist reasoning returns to the problem it had sought to overcome as it tacitly invokes the basis on which it first criticised formalism. There is no escape from the double bind of this argumentative structure. States are free and unfree at the same time. Like Odysseus self-bound to the mast of his ship, states are free to find ways and reasons to live with the Sirens - despite their bad beliefs and the

\footnotetext{
${ }^{23}$ Marti Koskennieni, 'The politics of international law' (1090) 1 Buropean Journal of International Law, 4-32, 10-11.

24 'J'homas Paine, Basic Writings of Thomas Paine: Common Sense, Rights of Man, Age of Reason (New York: Willey Book Co, 1942).
} 
dangers they pose to civilised seafarers. Conversely, states can break the double bind in one or both of two ways: by seeking to rule and dominate the Sirens on the basis of a universal law projected as an object of their own reflection and intentionality; or by seeking to transform, coerce, or otherwise civilise the Sirens into becoming members of the existing community of states.

\section{The law of occupatio bellica}

Part I has suggested that the structure of international law reflects a theory of liberal toleration. At issue in the tension and oscillation between formal and anti-formal modes of reasoning is the scope of that regime of toleration. In the UN Charter era, the 'flat substanceless surface' of Art. 2(1) of the Charter has been understood in strongly pluralistic terms. The sovereign equality of states has extended to republics, centrally planned socialist states, theocracies, kleptocracies, and modernising post-colonial territories. In more recent times, however, and especially since the end of the cold war, powerful Western states and the international institutions they control have advanced antipluralist arguments that seek to give greater moral substance to the criteria for tecognition as independent and equal subjects of international society. 'The criteria of inclusion and exclusion turn not on the external behaviour of states (which would raise familiar issues concerning the scope of the attributes of sovereignty) but rather on their internal identity.

The traditional law of belligerent occupation, however, does not allow for such an ambitious project of constitutional transformation. The formal rules of international law draw a clear distinction between occupatio bellica and debellatio: the former being a 'temporary state of fact arising when an invader achieves military control of a territory and administers it on a provisional basis, but has no legal entitlement to exercise the rights of the absent sovereign'; the latter being:

A legal category describing a condition of 'subjugation' in which the original sovereign is not merely temporarily incapacitated from exercising his powers due to the presence of the occupying military forces, but is completely defeated: his institutions of state destroyed, his international legal personality dissolved.",

25. Bhuta, 'The antinomies of transformative occupation', 725 . 
Thus, unlike debellatio, occupatio bellica is a mediating concept. While recognising the factual reality of an occupying power's military control of a territory, it imposes an obligation to maintain the continuity of the juridical and material constitution and to preserve the existing economic order of the state.

It should be noted, of course, that the notion of belligerent occupation is somewhat anomalous in the modern era. ${ }^{26}$ Articles 2(4) and 51 of the UN Charter forbid the use of force between states other than in selfdefence against an armed attack. The only other permissible basis for the occupation of a territory is under Chapter VII's collective security framework. Following the end of the cold war, the UN established transitional administrations to implement transformational state-building projects in territories such as Kosovo, East Timor and Cambodia. These cases are not necessarily inconsistent with occupation law's proscription of coercive transformation of a political system, as each involved the UN Security Council as in effect the "occupying power."?

The US project of 'occupation as liberation' in Iraq, however, presented a completely different situation. Whereas the UN Security Council had wholeheartedly supported, indeed created, those transitional UN administrations, here its role was unclear and bitterly contested. Far from authorising and legitimating the American transformative occupation, the relevant Security Council resolutions explicitly invoked occupatio bellica in designating the US and United Kingdom as occupying powers and requiring them to comply 'fully with their obligations under international law including in particular the Geneva Conventions of 1949 and the Hague Regulations of $1907^{\circ} .^{2.3}$ This not only resuscitated occupatio bellica and its preservationist ethos from its long desuetude

26 Ibiti, 722 (noting that, prior to the invasion of lraq, the category of belligerent occupation had fallen from use in the latiguage of state practice). See also Adam Moberts, "What is a military occupation?' (1985) 97 British Yearbook of International Law, 249-305.

27 Simon Chesterman, "Occupation as liberation: International humanitarian law and regime change' (2604) 18(3) Bthics and International Affairs, 51-64.

${ }^{28}$ SC Res, 1483 (22 May 2003), para, 5. See also SC Res. 1500 (14 August 2003). These Resolutions are sufficiently broad and ambiguous, however, to legitimate state-building activities well beyond occupato bellco's traditional order-preserving constraints, for example by calling for the establishment of 'national and local institutions of representative government', and the promotion of 'economic reconstruction' and 'Iegal and judicial reform': see SC Res, 1483 (22 May 2003), para. 8. For discussion of Resolution 1483 's 'rather unstable merger of the traditional rules of occupation with Security Conncil peacemaking powers under Chapter VII', see Hilary Charlesworth, 'I aw after war' (2007) 8 Melbourne Journal of International Law, 233-47, 239 -41 . 
in international politics, but did so arguably to restrain the occupant's authority unilaterally to transform Iraq's political order. ${ }^{29}$

'The US was thus confronted with obstacles established by formal legal rules on two fronts: on the one hand, transformative occupation was prohibited under the classical rules of occupatio bellica; on the other, it was permitted under modern international law but only according to the norms and procedures specified in the UN Charter. On both fronts instrumentalist arguments were needed to challenge the "excessive formalism' of the existing legal framework. Thus, for McGurk the preservationist principle of occupatio bellica was a 'state-centered, nineteenthcentury conception of European warfare ... bear[ing] no relation to modern military conflict or the contemporary thrust of public international law' ${ }^{30}$ Similarly, for Scheffer the series of UN-sponsored state-building projects since the 1990 s showed that the scope of permissible action under occupation law should be expanded if the occupied society requires 'revolutionary changes in its economy (including a leap into robust capitalism), rigorous implementation of international humanrights standards, a new constitution and judiciary, and a new political structure (most likely consistent with principles of democracy) ${ }^{37}$ As set out in the 2002 National Securty Strategy of the United States, the basic values of freedom, democracy and free enterprise - and importantly the duty of protecting them - are 'right and true for every person, in every society. ${ }^{\prime 2}$ If this is the case, then the formal rules of occupatio bellica are an obstacle to the right and must be amended or abandoned. Through this chain of reasoning, the mediating tension of the double bind is broken: the 'objective of instituting - even imposing - a democratic governance regime where previously there was none is [thus] asserted as the value relative to which positive legal rules should be adapted,.$^{3.3}$

In order to evaluate this argument, we need to explore the reasons behind the formalism of the classical occupatio bellica. How can we

29 See, e.g. Gregory H. Fox, "The occupation of Iraq' (2005) 36 Georgetown Joutmal of International Law, 195 297. For a contrary view, see John Yoo, "Iraqi teconstruction and the law of occupation' (2004) 11 Unlversity of Calformia Dawis Journal of International Law and Policy, $7-22$.

3t) Brett H. McGurk, 'Revisiting the law of nation-building: Iraq in transition' (2005) 45 Virginia joumal of Internationd Law, 45l-65, 458 .

31 David J. Scheffer, 'Beyond occupation law' (2003) 97 American Journal of International Law, 842-60, 849.

${ }^{32}$ George W. Bush, National Security Stratery of the United States of Amertca (Washington DC: United States White Honse, 2002), Preface.

33 Bhuta, 'The antinomies of transformative occtipation', 723 (emphasis added). 
explain the dual nature of this concept which legitimates the specified military aim of order-preservation while also imposing constraints in terms of order-constitutive authority enjoining the occupant's right to effect fundamental constitutional change? The answer lies in the history of the law of belligerent occupation as a mediating concept of territorial and constitutional change in nineteenth-century European intersovereign warfare. ${ }^{34}$ First, occupatio bellica applied only to wars between European sovereigns. It did not apply in the case of colonial wars or 'police actions' against less civilised (that is, non-sovereign, non-European) peoples and territories. ${ }^{35}$ Thus, in specific cases, such as the British occupation of Egypt or the Russian acquisition of Bulgaria, the 'very point of the war was to liberate a population from the antiquated and despotic constitutional system of the Ottoman Empire, and it would therefore be senseless to refrain from introducing a modern social and legal order. ${ }^{36}$ Second, the specific functional characteristics of occupatio bellica evolved in direct response to the French Revolution and ensuing revolutionary and Napoleonic wars which threatened to destroy the legal basis of the eighteenth-century European political order. These wars initiated constitutional change in place of conquest and ... attempted to radically transform the nature of the state and the accepted bases for territorial control. ${ }^{3 \%}$

The critical point here is that the formal law of occupatio bellica can be seen to embody the two normative and epistemological components of international legal argument discussed in Part I. In the first instance, struggles over the political principles that define international order cannot be mediated unless sovereign states recognise each other as legal subjects with a mutual 'duty of justification'. It is a common interest of all states that existing soveretgn authority should not be capable of being overthrown either internally (by revolution) or externally (by regime change). In the second instance, there is no universally prescriptive norm regarding the 'constitutional question' of the permissible scope and limits of internal political order. This argues for a degree of political pluralism such that states remain free to develop domestically according to their own circumstances.

Today, we interpret the refusal of the great powers to recognise non-European 'uncivilised' states as equal sovereigns as a moral failure

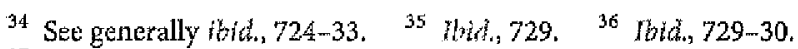

37 'The critical challenge here was the assertion by the French revolutionary government that 'rights based on popular soverejgnty transcended those based on treaties': see ihid, 730 . 
vitiating the possibility of an inclusive international legal order. At the same time, we recognise colonialism as an imperial attempt to impose a Eurocentric standard of constitutional order on peoples and territories lying outside of the jus publicum Europaetum. In both instances, the double bind of occupatio bellica was broken: in the case of the former, as a one-sided, self-centered account lacking external orientation towards the subjectivity of differently situated societies; in the case of the latter, as a one-sided, other-centered account lacking sensitivity towards the material values and ways of life of these societies.

A similar argumentative structure has shaped the positions taken under international law to justify the transformative occupation of Iraq. In the first instance, legal rules constraining the use of force and limiting the rights and authority of an occupying power have been held to be inapplicable in the case of Iraq. As an outlaw or rogue state ruled by dictatorship and in violation of basic human rights, the very purpose of regime change and occupation was to transform Iraq"s political order to bring it from the zone of politics into the zone of law of civilised nations. This argument rests on an instrumentalist view of the identity of the legal subject now unilaterally defined as the 'liberal democratic state'. By this move, the question of the rights and attributes of sovereignty is never in fact reached as the legal status of the subject as a 'sovereign state is denied a priori.

In the second instance, to the extent occupatio bellica was held to be applicable, its interpretation and application was determined solely by the US as the occupying power. Thus, its substantive meaning was expanded or amended to meet the needs and objectives of occupation. Security Council Resolution 1.483 (2003) is a contradictory bundle of formal and anti-formal provisions. On the one hand, it reaffirmed the 'sovereignty and territorial integrity of Iraq' and called for conditions to be established for Iraqis to 'freely determine their own political future'; on the other hand, it contemplated an extensive role to be played by the Coalition Provisional Authority (CPA) with only subsidiary roles assigned for both the UN and an interim Iraqi administration. ${ }^{38}$ While the US accepted its status as an occupying power in Iraq, it rejected any political co-ordination with or oversight by the UN Security Council, and retained absolute discretion as to the allocation of competences and

${ }^{38}$ See Charlesworth, 'Law after war', 239. 
functions in the transitional process. ${ }^{39}$ The CPA had virtually plenary governmental authority over the scope and terms of the remaking of the Iraqi economic and political order, and it acted accordingly. ${ }^{40}$

While the formal notion of occupatio bellica was thus revived, the US was able through a series of anti-formal moves to erase the basic distinction between sovereign power and occupant authority. ". The double bind of occupatio bellica was thus broken into two one-sided unities. From an anti-formal starting point, the US viewed the constraining function of the law of occupation as merely an unreal idealisation reflecting its own objectivity and immediacy. The reasons for orderpreservation make sense only if one first assumes an order worth preserving, or that "bad ... occupants are occupying a good country. Occupatio belica may well apply in cases of belligerent occupation of states objectively worthy of full sovereign recognition (for example, democratic or similarly decent states), but not otherwise. Albeit onesided, this is a tacitly naturalistic, formal position. Conversely, from a formal starting point, the US has viewed the legitimating function of occupation law as merely an object of its own reflection and intentionality, or that 'good occupants [are] occupying a bad country'. ${ }^{33}$ The cause is the political otder and ideology of the US itself as the directive controlling image and the effect has been to project a particular subjective conception of rationality onto the flat, substanceless surface of the legal form of occupatio bellica. 'This is an anti-formal particular masquerading as a universal.

\section{The law of international human rights}

The most striking reinterpretation of occupatio bellica's preservationist ethos in the Iraqi occupation has been the suggested right of the occupier to institute sweeping reforms to the political order in accordance with fundamental human-rights norms. 'This assertion gets to the heart of the paradox of 'occupation as liberation'. 'The belligerent occupant's

39 See generally Thomas D. Grant, "The security council and Iraq: An incremental practice" (2003) 97 Amertcan Joumal of Intemational Law, 823-42,853.

40 Bhuta, "I'he antitionies of transformative occupation", 736-37.

$41 \mathrm{Bid}$, , 737. See also Melissa Patterson, 'Who's got the title? or, 'The remuants of debellatio in post-invasion Ir'aq' (2006) 47 Harvard International Law Journal, 467-88, 474.

12 Adam Roberts, "Transformative military occupation: Applying the laws of war and human rights' (2006) 100 Anerican Journal of International Law, 580-622, 601.

13 libiu. 
authority to create the new political order based on democracy and human rights derives from force, from its prior achievement of military control over a subject people. However, as Bhuta argues:

'The occupent's ability to legitimate a new order in place of the old depends on his capacity to engender among the occupied population the belief, post facto, in the legitimacy of the occupant's 'naked power' as a precondition for' the new basic norm to which the occupied is subjected."it

The project of transformative occupation in this way turns on a precarious dialectic of subordination and legitimation: the military occupier has 'to subordinate before it can legitimate effectively, and the more it tries to subordinate, the harder becomes the legitimation'. ${ }^{1.5}$ Force alone, though necessary, is not sufficient for the new order to become firmly established. The subjects of occupation must cease their resistance and either acquiesce or consent to the basic norm that defines the new order. The desperate struggle for the occupier is to convince the occupied population not to resist its military dictatorship on the promise of the justice and legitimacy of the normative order being instantiated.

Having initially used sweeping anti-formal reasoning to reinterpret occupatio bellica to justify transformative occupation, the occupier in order to succeed in legitimating the norm of the new order - now switches to sweeping formalism. This is due to the danger that the human-rights norms sought to be legitimated will be challenged by the occupied population on anti-formalist grounds as ultimately subjective and thus illegitimate. Such an argument may proceed as follows: human rights, at least in the particular form they have assumed in international law, have tainted Western liberal origins; the West embodies an alien legal tradition premised on a stridently individualistic account of moral personality; and the 'universal' rights imposed by the occupier are thus merely another form of Western imperialism - universalising the tenets of a distinct tradition or 'being illiberal about being liberal, forcing people to be free. ${ }^{4}$ th

Such arguments challenging the formalism and claims to universality of international human-rights law raise difficult questions. Kennedy points to the fact that human-rights ideas have a particular time and

44 Bhuta, "The antinomies of transformative occupation", 738. ${ }^{45} 7 d d ., 724,739$.

${ }^{46} \mathrm{H}$. Patrick Glenn, Legol Traditions of the World: Sustainable diversity in law (Oxford: Oxford University Press, 2000), 245; Bhikhu Parekh, "The cultural particularity of liberal democracy' in David ITeld (ed), Prospects for Democracy: North, South, East, West (Cambridge: Polity Press, 1993), 156-75. 
place of origin - 'Post-enlightenment, rationalist, secular, Western, modern, capitalist' - and he argues that, to the extent the international human-rights project is linked to liberal Western ideas about the relationship among law, politics, and economics, it is itself 'part of the problem'." Kennedy's critique has relevance to the transformative occupation of Iraq in at least two main areas. The first concerns the particular form of secularism associated with Western liberalism and its relationship to religion.

If you thought secularism was part of what is bad about the modern West, you might assert that human rights shares the secular spirit; that as a sentimental vocabulary of devotion it actively displaces religion, offering itself as a poor substitute. You might claim that the enforcement of human rights, including religious rights, downgrades religion to a matter of private and individual commitment, or otherwise advances the secular project. ${ }^{48}$

The second concerns the way that human rights positions itself as an 'emancipatory political project' that operates outside politics. The implicit logic here is that:

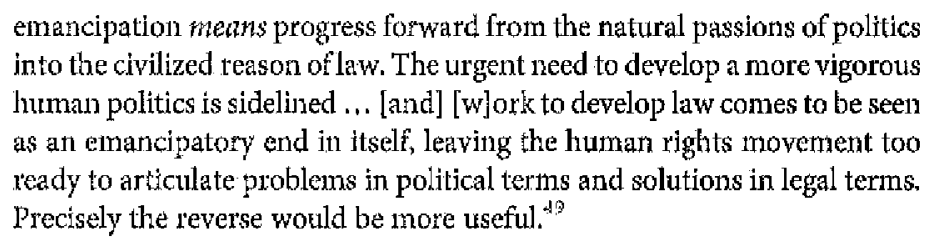

These challenges to the universality of human rights apply with special resonance in the case of Iraq, a non-Western society where Islam is dominant and collective identities and affiliations are engrained in all aspects of social and political life. Accordingly, we can appreciate how a formal human-rights norm - for example, the right to freedom of religion and belief - may be met with strong anti-formal claims to a distinct Islamic conception of that norn. The argument may go that the 'universal' norm is underpinned by a particular comprehensive conception of the good (for example, a liberal account of moral personality and personal autonomy) which generates an ultimately subjective and contested view of the relationship between the religious and the secular. However, international human-rights law is unable to provide a

${ }^{47}$ David Kennedy, "The international human rights movement: Part of the problem?" (2002) 15 Harvard Himan Rights Journah, 101-25, 114-15.

48 ibid. Whid, 115 . 
universal answer regarding the truth of the good and thus show that all other comprehensive beliefs are false. On this basis, human-rights norms themselves must be intersubjectively contested as opposed to uncritically accepted as a legal fait accompli beyond politics. The moral duty of justification and the twin criteria of reciprocity and generality thus support Kennedy's view that the human-rights dilemmas at issue in the new Iraqi constitutional order are better articulated in legal terms and their solutions in political terms than vice versa.

In response to arguments of this kind, the occupier will insist that the norms that are to ground the new political order are not uniquely Western but are universal values embedded in (formal) international instruments such as the Universal Declaration of Human Rights and the International Covenant on Civil and Political Rights (ICCPR).$^{50}$ Indeed, any groups or individuals resisting these norms are to be viewed as enemies not just of America or the West, but of humanity. ${ }^{51}$ Conversely, those groups and individuals recognising and consenting to these norms are permitted to enter the community of civilised nations.

A complex and conflicted response to this dialectic can be seen amongst the occupied population. For some, the imperial designs of the occupier remain evident and resistance by force is urged until the occupation is ended and national self-determination assured. But for those engaging in the transitional political process, two general sensibilities emerge. The first is one of capitulation and consent: the constitutive coercion of the occupier and the new political order should be accepted precisely so as to accept the principles, laws and rules observed by international society. This is a formal 'universalist' sensibility. The second position, however, is more one of acquiescence: while it is necessary to follow the rules of international law and be part of the community of nations, the occupied population has its own unique identity, history, culture and legal consciousness. 'T'hus, having initially insisted on the formalism of occupatio bellica (and other legal norms such as the prohibition on the use of force and self-determination), an anti-formal argument is now made on the basis of a regional, national or religious uniqueness and consciousness challenging the formalism and claims to universality of international law. This is an anti-formal 'regionalist' or 'particularist' disposition.

50" See McGurk, 'Revisiting the law of nation-building', 463 .

S1 Recall Carl Schmitt's statement that 'He who unvokes humanity wants to chent': Carl Schmit, The Concept of the Political (Chicago: University of Chicago Press, 1996), 54. 
This universalist-regionalist dialectic is a familiar phenomenon in the politics of international law. It is clearly seen, for example, in the nineteenth-century debate between Alejandro Alvarez and Manoel Alvaro de Souza Sá Vianna over the role of international law in Latin America (a debate itself spurred in response to US hegemony in the region). For Vianna, the 'problems common to the countries of Latin America or the American continent did not and could not constitute a basis for an autonomous or separate sphere of international law. ${ }^{\text {.2. This meant: }}$

faworing the tuniwersality of international law, defined by a formalist legal sensibility that was skeptical of regional integration, unconvinced by the advantages of introducing regional fragmentation to the international system, and had an agenda to pursue within professional circles as opposed to regional political institutions. ${ }^{\text {s3 }}$

For Alvarez, however, appreciation of a unique "Creole legal consciousness' led him to advocate a regional perspective in international law: a 'socially conscious and practical universal international law which took into account regional differences'. ".4. This meant 'endorsing an antiformalist legal sensibility coupled with positivist political ideas and integrationist aspirations. ${ }^{35}$ Through the notion of Latin American international law, particularist international lawyers sought to develop an autonomous regional identity in international law while transposing and nationalising a 'modernist liberal agenda' in domestic politics seeking to overcome colonial legacies. For these lawyers, the binarism of the international legal double-bind thus operated in two directions: first, as an external restraint in the form of a set of norms on the rights and duties of states shaped by European particularisms; second, and in response, as an internal enabling force legitimating the notion of a unique Creole identity and consciousness. Conversely, universalist international lawyers rejected any notion of a Latin American international law and sought full entry into the community of nations while supporting conservative policies at the domestic level. Here the double bind operated in the reverse direction: first, as an external enabing force allowing the state

52 Ifliana Obregón, 'Between civilization and barbarism: Creole interventions in international law' (2006) 27 'Third Word Quarterly, 815-32, 816.

53 Anulf Becker Iorca, "International law in Latin America or Latin American inter. national law? Rise, fall, and retrieval of a tradition of legal thinking and political imagination" (2006) 47 Harvard international Law Journal, 283-305, 301.

54 See Liliana Obregon, 'Noted for dissent: The international life of Alejandro Alvarez' (2006) 19 Leiden Journal of International Law, 983-1016, 1015.

55 Lorca, 'Internationa' law in Latin America or Latin American international law?', 301. 
to enter the sphere of law which 'governs the relationship of civilized peoples [and] does not admit distinctions, nor supremacy of any sort'; and second, as an internal restraint on any emancipatory or progressive domestic political movements. The former sensibility starts from the anti-formal particular - from the situated or social self - and leads towards the universal reaching a 'concrete universal'. The latter sensibility starts from the formal universal -- from a set of abstract legal rules and leads towards the particular reaching an 'abstract particularism1."

This same dialectic structure has emerged among the various political factions during the transitional political process in occupied Iraq. "This can most clearly be seen in the struggles over the relationship between Islam (and religion more broadly) and the state under the new Iraqi constitutional order. The story begins on 13 July 2003 with the appointment of a twenty-five-member Iraqi Governing Council (IGC), which on 8 March 2004 signed a Transitional Administrative Law (TAL) ${ }^{58}$ The TAL was an exhortatory document with a distinctly liberal orientation. The preamble reasserted the sovereignty of the people of Iraq, expressed a commitment to international law, and stated that the TAL was being established to 'govern the affairs of Iraq during the transitional period until a duly elected goverument, operating under a permanent and legitimate constitution achieving full democracy, shall come into being'. Article 2 of the TAL divided the transitional period into two phases, the first vesting authority in a sovereign interim government appointed by the CPA in consultation with the UN; the second vesting authority in a transitional government to be established following elections in January $2005.9 \%$ Significantly, Art. 4 declared that the 'system of government in Iraq shall be republican, federal, democratic, and pluralist". ${ }^{60}$ On the

56 Carlos Calvo, Poldmica Calvo-Alcorta [The Calvo-Alcorta Polemic] (1883) 8 Nueva Revista de Buenos Aires, 629, 631 .

57 Lorca, "International law in Latin America or Latin American international law?", 288-93.

58 Law of Administration for the State of 1 aq for the Transitional Period (8 March 2004) avaliable at www.globalsecurity.org/wmd/libraxy/news/iraq/2004/03/iraq-transitionaladministration-law_8mar2004.htm.

59 For al-Istrabadi, these two phases involved transfers of authouty, not sovercignty: Feisal Amin al-Istrabadi, Reviving constitutionalism in Iraq: Key provisions of the Transitional Administrative Law' (2005-2006) 50 New York Law School Law Review, $269-302,274$

60 It is interesting to note that this wording closely tracks the 1992 Articles of Association of the Iraqi National Congress (the group of Iraqi exiles who lobbied in the West for the forced removal of the Saddam Hussein regime). See Noah Feldman and Roman Martinez, "Corastitutional politics and text in the new Iraq: An experiment in Islamic democracy' (2006) 75 Fordham Law Review 883-920, 889. 
contentious issue of the role of religion in the new Iraqi constitutional order, however, Art. 7(A) stated that 'Islam is the official religion of the State and is to be considered a source of legislation'. The second part of this sentence represented a decisive change in Iraq's constitutional history. While it had long been established that Islam was the official state religion, for the first time Islam was here expressly declared to be a 'source' of law.

Already evident in the 'TAL were signs of what would become a major site of disagreement. After the 2003 invasion and overthrow of Saddam Hussein, the former exiled members of the Iraqi National Congress (INC) and other members of a coalition ${ }^{6}$ formed the leadership of the IGC operating under the auspices of the CPA. Their vision of the constitutional foundations of the new Iraq was close to that of the occupying powers and thus, for the Americans, the TAL represented a vindication of their policy of regime change and democratic transformation. Indeed, the Bush administration strongly supported the secular Iraqis among the exile group who favoured a Kemalist-style constitution on the Turkish model - one which rejected a public role for Islam and posited instead a society of 'science, knowledge, and civilization'. 'To the extent that Islam was to have a larger role, the US lobbied negotiators involved in the drafting process to ensure that this would not impinge upon religious freedom, women's rights, or an independent Iraqi judiciary. ${ }^{62}$ On the other hand, these policy objectives were also complicated by the participation of two other (non-exile) Iraqi groups in the constitution-drafting project: Sunni Arabs and the Grand Ayatollah Ali al-Sistani. ${ }^{6.3}$ Sistani insisted that the constitution be drafted by a democratically elected body in order to avoid a constitution being imposed or overly influenced by the US, and to ensure that the drafting body reflected Irag's demographic make-up (which is majority Shia). He then issued a religious mandate ordering Iraqi men and women to vote.

National elections were held on 31 January 2005, and the first session of a 275 -member Transitional National Assembly (T'NA) replacing the interim government was convened on 16 March 2005. The TNA then produced a draft constitution which barely won approval via referendum at the end of 2005 in preparation for a permanent constitution, which in

61 'This coalition was made up mainly of Kurdish factions (who advocated a secular political order fearing that Saddam's secular tranny would be replaced by a Shia Islamic dictatorship), Shia opposition groups such as the Da ${ }^{2}$ wa Party founded in the late 1950 s and the Supreme Cotucil for the Islanic Revolution in Iraq (SCIRT); and other secular and independent political parties: see ibid., 888 .

62 bath, 898 . 63 Wit., 890-1. 
February 2008 remains in the ratification process. There is no single text of the draft Lraqi constitution. As of 15 August 2005, there were two versions in existence: one, the Shia-driven TNA Constitutional Committee draft; the other, the leadership-summit document drafted by the Kurds and secular Shia and Sunnis. Article 2 of the 2005 constitution provides:

First: Islam is the offcial religion of the State and it is a foundation source of legislation:

(a) No law that contradicts the established provisions of Islam may be enacted.

(b) No law that contradicts the principles of democracy may be enacted.

(c) No law that contradicts the rights and basic freedoms stipulated in this Constitution may be established.

Second: This Constitution guarantees the Islamic identity of the majority of the Iraqi people and protects the full religious rights to freedom of religious belief and practice of all individuals such as Christians, Yazidis and Mandean Sabeans.

While the decision to make Istam the official state religion was not controversial, ${ }^{\text {G. }}$ what was intensely debated was the extent to which Islam should be recognised as a source of law. Certain Shia Islamists, particularly members of the Supreme Council for the Islamic Revolution in Iraq (SCIRI), argued that Islam should be 'the basic or fundamental' source of legislation. Other modifiers, such as 'principal' or 'amongst other sources of legislation', also found support from the Shia religious participants. The Kurdish representatives, however, advocated strongly that Islam should be only one of several sources and proposed following Art. 7(A) of the 'TAL: 'Islam ... is a source of legislation'. The final formulation of Islam as a 'foundation source' is thus a compromise between the positions of the Shia and Kurdish groups. ${ }^{65}$ It appears to leave the issue of hierarchy of sources of law open and ambiguous, with Islam not necessarily superior to, but standing alongside, other fundamental sources of law (although no other fundamental sources are expressly recognised). ${ }^{66}$

64 Although a Shia proposal to describe Irac as an 'Islamic state' was strongly opposed and subsequently rejected. See Ashley S. Deeks and Matthew D. Burton, 'Iraq's constitution: A drafting history' (2007) 40 Cornell International Law Journal, 1-87, fo 13.

65 ibit., 3 .

66 There remains confusion regarding the two Iraqi words of 'asasi' and 'asas'. "The former is an adjective best translated as 'fundamental', whereas the latter is a noun best translated as 'foundation'. In the UN printing of the text, the drafters changed asasi to asas, hence 
Clauses (a) to (c) of Art. 2 are referred to as the 'repugnancy' or 'noncontradiction' clauses. Shia negotiators supported the phrase 'established provisions' in clatuse (a) because it suggested a broader incorporation of Islam into the constitution. Non-Shia negotiators objected, however, because this connoted too wide-ranging a field of Islamic jurisprudence against which Iraqi law could then be measured. Other secularists further feared that the language could incorporate fatwas, or rulings issued by religious scholars, as a type of legal ruling. From the other side, Sunni negotiators opposed the phrase 'established provisions', and supported a less Islamic formulation, as they believed that the 'provisions' or 'rulings' thus incorporated would derive only from Shia Islam.

The phrases 'principles of democracy' and 'rights and basic freedoms stipulated in this constitution' in clauses (b) and (c) were proposed as an attempt to place a limit on the notion of Islam as a foundation source of law. The language also made clear that the constitution is the supreme law over ordinary federal or local statutes. Shia negotiators opposed this language but could not win over the combined Kurdish and secular negotiators who wanted non-contradiction clauses that counter-balanced the 'established provisions of Islam' language in clause (a). The idea was that the presence of these parallel non-contradiction clauses would operate to 'equalise' Islam with the principles of democracy and basic human rights. 'This, in other words, was an attempt to establish the constitutional framework for an 'Islamic democracy' in the new Iraq.

There was also significant political struggle in relation to the second part of Art. 2. Article 7(A) of the TAI, had formerly provided that "This law respects the Islamic identity of the majority of the Iraqi people and guarantees the full religious rights of all individuals to freedom of religious belief and practice'. While earlier versions of the text provided that the constitution 'respects' the Islamic iclentity of the majority, Shia negotiators fought hard to have 'respect' replaced with 'guarantees'. This raises the complex legal question of what it means to 'guarantee the Islamic identity of the majority of Iraqis' and whether this provision could lead to measures that limit the religious freedom of

the current formulation of Islam as 'a foundation source". Whether this is merely symbolic or has juridical inportance is an open question, See bid., 10 (suggesting that the 'latent ambiguity in this provision will prove to be a source of future sectarian dissension'). 
non-Muslims. ${ }^{67}$ In addition, earlier attempts to create an exclusive list of groups entitled to the religious rights at issue were finally superseded on 26 August 2005 with language that added a specific, non-exclusive list of ethno-religious groups to a generic reference 'all individuals ${ }^{2} .68$ Much like Art. 27 of the ICCPR, this provision thus proposes an ambiguous combination of individual and group rights. The Kurds argued that it was important to include 'others' in the list of religious groups and that the list should not be exclusive. Others objected on the ground that using the phrase 'and others' would marginalise or stigmatise all minority groups in this 'other' category. In the end, the words 'and others' were rejected, though all negotiators seemed to share the view that the list remained non-exclusive. ${ }^{65}$

These struggles over the normative structure of the new Iraqi constitutional order represent a collision between two competing sets of positions and understandings of the basic norms defining political order. Under basic precepts of liberal democratic theory, religion cannot be a formal 'source' of law; this is reserved to secular sources of constitutional and domestic legal norms. Consistent with the Enlightenment premises of individual freedom and personal autonomy, the rule of law is by definition a secular project in which religion is transferred from the sphere of public reason to the sphere of 'private' conscience and belief. For the occupiers, stich ideas define not just liberal constitutionalism but international human-rights law itself: they are in this respect universal. For the INC and the leadership of the IGC, this formal universalist sensibility is to be embraced. Like Vianna and the universalist Latin American international lawyers of the nineteenth century, this is the means for Iraq to re-enter the sphere of the community of nations with the same rights and duties as the other advanced states of the world. If Islam is to be a source of law, it must be qualified by or at least stand equally with democratic principles and basic rights and freedoms. Starting from an initial position of formal universality, this is the form of 'abstract particularism' finally reached.

${ }^{67}$ See, e.g, ibis., 17, citing Nima Shea and John F. Cullinan, "Constitutional concerns", National Review Onithe (29 August 2005); United States Commission on International Religious Freedom, Iraq's Permanent Constilution: Analysis and recommendations (Washington DC: United States Commission on International Religious Freedom, March 2006).

68 The freedom to choose ane's religion or belief is not specified in Art, 2, Cf, International Covenant on Civil and Political Rights, opened for signature 19 December 1966, 999 UNTS 171, Art. 18 (entered into force 23 March 1976).

${ }_{69}$ Deeks and Burton, 'Iraq's constitution', 17-18. 
However, for the other Iraqi factions these positions appear both antiformal and subjective. Like Alvarez and the particularist Latin American lawyers, international human-rights law is seen to be shaped by, and based on, Anglo-European precepts that must be contested in the quite different normative context of Iraqi conceptions of constitutional order and society. This means advancing a competing anti-formal legal sensibility based on a unique collective identity and legal consciousness. If for the occupiers religion must find its place within a liberal democratic order, then for the Iraqis democratic and human-rights norms must find their place within an Islamic legal order. The ultimate basis of sovereign authority is quite different. Starting from an initial position of the antiformal particular (as do the occupying powers themselves), this is the form of 'concrete universal' that is finally reached. We can see this most clearly in the struggle over the second part of Art. 2: it is not sufficient for the constitution to 'respect' the Islamic identity of the majority of the Iragi people, it must 'guarantee' it. This is the basis of the constitution itself. Within that normative framework, the 'full rights' to freedom of religion and belief of other groups and individuals must be protected. Unlike liberal theories of rights, however, this does not mean a 'neutral" state protecting a general right to 'equal concern and respect'. Rather, it suggests a conception of a 'socially conscious and practical universal international law which ... [takes] into account regional differences" ${ }^{70}$

\section{Conclusion}

The transformative occupation of Iraq provides a powerful illustration of the two dominant critiques of formalism in international legal discourse today: one rejecting formal sovereign equality on moral grounds because it places democratic and rogue states on the same footing; the other rejecting the formal rules of state sovereignty on the basis of a particular ethical conception of the good. The discussion of occupatio bellica in Part II demonstrated how the former threatens international law's underlying commitment to value pluralism and its denial of the legal right of any one state to impose a single model of political order. The discussion of human rights in Part III demonstrated how the latter project of imperial democratisation has precipitated a collision between two ultimately incommensurable positions: liberal anti-pluralism and national self-determination. The ensuing struggle within Iraq over these

${ }^{70}$ See Obregón, 'Noted for dissent', 1015. 
competing bases of political legitimacy are the twin blactes of the shears that are threatening to cut to shreds the future of the Iraqi constitutional order: one abstract but reaching for the particular; the other concrete but reaching for the universal. The role of international law in this fraught post-conflict dialectic has been shown to be at once ambiguous and paradoxical: both facilitating the external instrumentalist project of subordinating a resistant political order, while at the same time creating a formal site necessary for the internal deliberation, contestation and resistance to that project. While the justice of any position taken in the struggle will remain fiercely contested, the one thing of which we can be certain is the inevitability of transformation. 